\title{
Effects of digestate solid fraction fertilisation on yield and soil carbon dioxide emission in a horticulture succession
}

\author{
Carmelo Maucieri, Carlo Nicoletto, Caterina Caruso, Paolo Sambo, Maurizio Borin \\ Department of Agronomy, Food, Natural resources, Animals and Environment, University of Padua, \\ Legnaro (PD), Italy
}

\begin{abstract}
The aim of this study was to evaluate the agronomical and environmental effects of digestate solid fraction (DSF) used as fertiliser in a vegetable crop succession (green bean, savoy cabbage, cabbage and cauliflower) in Northeast Italy $\left(45^{\circ} 20^{\prime} \mathrm{N} ; 1^{\circ} 57^{\prime} \mathrm{E}\right)$. Three fertilisation treatments were tested using DSF to substitute $0 \%$ (Tmin), 50\% (T50) and 100\% (T100) optimal level of mineral nitrogen fertilisation. The experiment was carried out from $22^{\text {nd }}$ May 2014 (green bean sowing) to $3^{\text {rd }}$ June 2015 (cabbage harvest). Summer and spring crops did not show significantly different marketable yield among fertilisation treatments with an average value ( \pm standard error) of $9.0 \pm 0.5,9.9 \pm 1.2$ and $51.3 \pm 6.4 \mathrm{Mg}$ $\mathrm{ha}^{-1}$ for green bean, cauliflower and cabbage, respectively. Lower DSF fertilisation effect was monitored on winter crop (savoy cabbage) with a marketable yield reduction of $-35.1 \%$ than mineral fertilisation $\left(25.9 \mathrm{Mg} \mathrm{ha}^{-1}\right.$ ), whereas the $\mathrm{T} 50$ treatment was not significantly different compared to the two previous ones. Crop species significantly influenced the $\mathrm{N}$ use efficiencies with negative recovery and use efficiency indexes for the DSF fertilisation treatments. Soil $\mathrm{CO}_{2}$ emissions were not significantly influenced by fertilisation in all studied crops with median values always lower than $1 \mathrm{~g} \mathrm{~m}^{-2} \mathrm{~h}^{-1}$.
\end{abstract}

Correspondence: Carlo Nicoletto, Department of Agronomy, Food, Natural resources, Animals and Environment, University of Padua, Agripolis Campus, Viale dell'Università 16, 35020 Legnaro (PD), Italy. Tel: +39.049.8272826 - Fax: +39.049.8272839.

E-mail: carlo.nicoletto@unipd.it

Key words: Cabbage; Cauliflower; Green bean; Savoy cabbage; Nitrogen.

Acknowledgments: research was supported by ValDige project Valorizzazione del digestato per la riduzione delle perdite di $\mathrm{CO}_{2}$ DGR $\mathrm{n}^{\circ} 1604$ del 31/07/2012 financed by PSR Veneto Region (2007-2014) measure 124, Protocol n. 2307827.

Received for publication: 16 June 2016.

Revision received: 20 December 2016.

Accepted for publication: 7 January 2017.

CCopyright C. Maucieri et al., 2017

Licensee PAGEPress, Italy

Italian Journal of Agronomy 2017; 12:800

doi:10.4081/ija.2017.800

This article is distributed under the terms of the Creative Commons Attribution Noncommercial License (by-nc 4.0) which permits any noncommercial use, distribution, and reproduction in any medium, provided the original author(s) and source are credited.

\section{Introduction}

The biomass anaerobic digestion for biogas production is one of the most promising renewable energy forms. Together with biogas, anaerobic digestion produces a residual material (digestate) whose adequate management or disposal must be addressed in order to avoid any constraint to the development of anaerobic digestion systems (Alburquerque et al., 2012) and improve the sustainability of this renewable energy form production (Teglia et al., 2011). Considering digestate characteristic chemical composition (Tambone et al., 2010), biological stability (Tambone et al., 2009) and the higher hygienic quality of digestate than input biomasses (Bonetta et al., 2011; Goberna et al., 2011) it could be used in agriculture as organic fertiliser (Cavalli et al., 2014; Nkoa, 2014) with positive effects on social, productive and environmental problems. In fact, intensive agriculture has caused social and environmental problems worldwide over the few past decades and some of the most important impacts are loss of soil organic matter, soil erosion and water pollution (Zhao et al., 2009). In the last years interest in the use of organic matrices in agriculture has been increasing due to the high cost of mineral fertilisers and new environmental regulations that limit their use. The recycling of organic waste materials can help maintain soil organic matter and nutrients levels, and exert positive effects on various aspects of soil fertility (Casacchia et al., 2012; Marchetti et al., 2012; Barbera et al., 2013). On the other hand, organic matter addition can promote soil greenhouse gases emission, such as carbon dioxide $\left(\mathrm{CO}_{2}\right)(\mathrm{Li}$ et al., 2013), stimulating soil microbial activity. It is generally accepted that the quality of organic matter influences microbial activity. Particularly, the increase in soil organic matter decomposition rate after fresh organic matter input to soil, is often supposed to result from a global increase in microbial activity due to the higher availability of energy released from the decomposition of fresh organic matter (Fontaine et al., 2003). In view of this, stable organic waste materials should be added to the soil to increase the soil organic matter content and to reduce soil $\mathrm{CO}_{2}$ emission. During anaerobic digestion the easily degradable organic compounds is mineralised obtaining as output digested organic material characterised by more stable organic matter (Marcato et al., 2009; Tambone et al., 2009). It has been found in laboratory condition that soil microbial activity is reduced when organic residues are anaerobically digested before it distribution in the soil (Thomsen et al., 2013), indicating that the organic matter in the digestate can hardly be used as carbon and energy source by soil microorganisms (Bachmann et al., 2014).

A few conflicting results about the effect of digestates on crop yields have been recently reported in the literature (Möller and Müller, 2012) with results that can be grouped into three categories of performances: similar to the unfertilised control, similar or higher than undigested feedstock and equal or better than mineral fertilisers (Nkoa, 2014). Suboptimal performances of diges- 
tate involved inappropriate storage and/or application techniques that can lead to the loss of its fertiliser value or nitrogen use efficiency, through ammonia volatilisation, leaching and runoff into surface and ground waters (Nkoa, 2014). Several studies have investigated the effect of digestate fertilisation, especially on cereal and/or biomass production (Loria et al., 2007; Chantigny et al., 2008; Bachmann et al., 2014; Maucieri et al., 2016). Considering digestate effect on vegetables production literature data are also present, but several studies consider: i) one crop cycle (Hossain et al., 2014); ii) the cycles of the same species in different years (Montemurro et al., 2010; Lošák et al., 2016); iii) different cycles of one species in the same year (Nicoletto et al., 2014). Few studies consider the continuous use of digestate in a vegetable crop succession (Alburquerque et al., 2012). With this in mind, the aim of this study was to evaluate the agronomical and environmental (soil $\mathrm{CO}_{2}$ emission) effects of the digestate solid fraction (DSF) use as nitrogen source in a vegetable crop succession.

\section{Materials and methods}

\section{Experimental description}

The trial was carried out at the Experimental Farm of Padua University at Legnaro, North-East Italy $\left(45^{\circ} 20^{\prime} \mathrm{N} ; 1^{\circ} 57^{\prime} \mathrm{E}\right)$ in open field conditions using DSF on green bean (Phaseolus vulgaris L.,), savoy cabbage (Brassica oleracea var. sabauda L.), cabbage (Brassica oleracea var. capitata) and cauliflower (Brassica oleracea var. botrytis).

Three fertilisation treatments were tested using DSF to substitute mineral nitrogen $(\mathrm{N})$ crop requirements: i) $50 \% \mathrm{~N}$ through $\mathrm{DSF}$ and $50 \% \mathrm{~N}$ through mineral fertiliser (T50); ii) $100 \% \mathrm{~N}$ through DSF (T100); iii) 100\% mineral fertilisation (Tmin). DSF derived from a process of anaerobic digestion of cattle slurry and manure, maize silage and flour; its chemical composition is reported in Table 1.

The phosphorus $(\mathrm{P})$ and potassium $(\mathrm{K})$ content in the DSF were taken into consideration to calculate the amount of these elements to supply as mineral fertilisers in the different treatments (Table 2) to obtain the same amount. When P or K supplied with DSF in the T50 and/or T100 treatments were lower than the optimal dose supplied in the Tmin treatment the difference was integrated with mineral fertilisers. This fertilisation management was chosen to highlight the effects of the form in which the $\mathrm{N}$ was supplied.

$\mathrm{N}, \mathrm{P}$ and $\mathrm{K}$ rates from mineral fertilisers were supplied according to standard recommendations in the area: $40,50,100 \mathrm{~kg} \mathrm{ha}^{-1}$ for green bean and $110,70,160 \mathrm{~kg} \mathrm{ha}^{-1}$ for the other species respectively for $\mathrm{N}, \mathrm{P}_{2} \mathrm{O}_{5}$ and $\mathrm{K}_{2} \mathrm{O}$ (Perelli et al., 2009). Both mineral and DSF were supplied from 1 to 4 days before sowing or transplanting and immediately incorporated by rotavator.

The soil was a fulvi-calcaric Cambisol with a loamy texture; its chemical characteristics, determined before the beginning of the experiment, are reported in Table 3.

A randomised block experimental design with three replications was used and plots were $40 \mathrm{~m}^{2}$ wide $(10 \mathrm{~m} \times 4 \mathrm{~m})$. The green bean was sowed on 22 May 2014 and harvested on 14 July 2014, savoy cabbage was transplanted on 12 August 2014 and harvested on 15 January 2015. After, each plot was split into two subplots of $20 \mathrm{~m}^{2}(10 \mathrm{~m} \times 2 \mathrm{~m})$ and both cabbage and cauliflower were together grown transplanting them on 3 April 2015. Cauliflower was harvested on 27 May 2015 and the cabbage on 3 June 2015.

\section{Meteorological variables}

The following meteorological data were recorded by the weather station that was close to the experimental site: rain $(\mathrm{mm})$, max, min and average air temperature $\left({ }^{\circ} \mathrm{C}\right)$, wind speed $\left(\mathrm{m} \mathrm{s}^{-1}\right)$, relative humidity $(\%)$, and solar radiation $\left(\mathrm{MJ} \mathrm{m}^{-2} \mathrm{~d}^{-1}\right)$.

\section{Plants harvest and measurements}

Crops were harvested at full crop marketable maturity in a subarea of $4.5 \mathrm{~m}^{2}$ in the inner part of each plot to determine: total biomass production, marketable yield and waste biomass. Marketable harvest index was calculated using the following equations:

Harvest index $(\mathrm{HI})=$ Marketable fresh biomass/Total fresh biomass

For each plot, the marketable and waste biomass of five plants were cut into small pieces and dried in a ventilated oven at $65^{\circ} \mathrm{C}$ to calculate the dry matter content. In this last, the total organic nitrogen content was determined according to ISO1656 method.

\section{Soil carbon dioxide flux measurement}

$\mathrm{CO}_{2}$ flux was measured with the static non-stationary chamber technique (Maucieri et al., 2016) using a chamber with a volume of 5 $\mathrm{L}$ and $10 \mathrm{~cm}$ square base. $\mathrm{CO}_{2}$ emissions were detected in two points of each plot in order to replicate the measures in the space with 6 measures for each studied treatment. Soil $\mathrm{CO}_{2}$ emission was measured 13 times during green bean crop season and 12 times during the crop seasons of the other species. For savoy cabbage soil $\mathrm{CO}_{2}$ emissions were not detected from half October till the first week of December.

Table 1. Chemical characteristics of digestate solid fraction used in the experiment.

\begin{tabular}{lc}
\hline Parameters & Values \\
Electrical conductivity $\left(\mathrm{dS} \mathrm{m}^{-1}\right)$ & 1.15 \\
$\mathrm{pH}$ & 8.9 \\
\hline Dry matter (\%) & 22.6 \\
Organic carbon (\%) & 51.5 \\
\hline Total organic nitrogen (\%) & 1.9 \\
$\mathrm{NH}_{4}\left(\mathrm{mg} \mathrm{kg}^{-1} \mathrm{DM}\right)$ & 10012.7 \\
$\mathrm{NO}_{3}\left(\mathrm{mg} \mathrm{kg}^{-1} \mathrm{DM}\right)$ & 395.7 \\
$\mathrm{PO}_{4}\left(\mathrm{mg} \mathrm{kg}^{-1} \mathrm{DM}\right)$ & 4265.9 \\
\hline $\mathrm{P}\left(\mathrm{mg} \mathrm{kg}^{-1} \mathrm{DM}\right)$ & 10229.6 \\
$\mathrm{~K}\left(\mathrm{mg} \mathrm{kg}^{-1} \mathrm{DM}\right)$ & 13938.9 \\
\hline $\mathrm{Ca}\left(\mathrm{mg} \mathrm{kg}^{-1} \mathrm{DM}\right)$ & 6295.8 \\
$\mathrm{Na}\left(\mathrm{mg} \mathrm{kg}^{-1} \mathrm{DM}\right)$ & 2249.3 \\
$\mathrm{Mg}\left(\mathrm{mg} \mathrm{kg}^{-1} \mathrm{DM}\right)$ & 3656.5 \\
$\mathrm{Cl}\left(\mathrm{mg} \mathrm{kg}^{-1} \mathrm{DM}\right)$ & 5062.0 \\
\hline $\mathrm{SO}{ }_{4}^{-}\left(\mathrm{mg} \mathrm{kg}^{-1} \mathrm{DM}\right)$ & 1692.7 \\
$\mathrm{Cd}\left(\mathrm{mg} \mathrm{kg}^{-1} \mathrm{DM}\right)$ & $<0.001$ \\
\hline $\mathrm{Cr}\left(\mathrm{mg} \mathrm{kg}^{-1} \mathrm{DM}\right)$ & 1.0 \\
$\mathrm{Cu}\left(\mathrm{mg} \mathrm{kg}^{-1} \mathrm{DM}\right)$ & 7.0 \\
\hline $\mathrm{Hg}\left(\mathrm{mg} \mathrm{kg}^{-1} \mathrm{DM}\right)$ & $<0.001$ \\
$\mathrm{Ni}\left(\mathrm{mg} \mathrm{kg}^{-1} \mathrm{DM}\right)$ & 1.2 \\
\hline $\mathrm{Pb}\left(\mathrm{mg} \mathrm{kg}^{-1} \mathrm{DM}\right)$ & 0.1 \\
$\mathrm{Zn}\left(\mathrm{mg} \mathrm{kg}^{-1} \mathrm{DM}\right)$ & 130.7 \\
\hline $\mathrm{DM}, \mathrm{dry} \mathrm{matter.}^{-1}$ &
\end{tabular}


Soil $\mathrm{CO}_{2}$ flux was determined by measuring the temporal change in $\mathrm{CO}_{2}$ concentration inside the chamber using a portable IR instrument (Geotech G150), detecting $\mathrm{CO}_{2}$ concentrations at levels of parts per million. $\mathrm{CO}_{2}$ flux was calculated using the following formula:

$\mathrm{CO}_{2}=\mathrm{V} / \mathrm{A} \cdot \mathrm{dc} / \mathrm{dt}$

where $\mathrm{CO}_{2}$ flux is expressed in $\mathrm{mg} \mathrm{CO}_{2} \mathrm{~m}^{-2} \mathrm{~s}^{-1} ; \mathrm{V}\left(\mathrm{m}^{3}\right)$ is the volume and $\mathrm{A}\left(\mathrm{m}^{2}\right)$ the footprint of the flux chamber; $\mathrm{c}$ is the $\mathrm{CO}_{2}$ concentration $\left(\mathrm{mg} \mathrm{CO}_{2} \mathrm{~m}^{-3}\right)$ and the time step (s).

In each $\mathrm{CO}_{2}$ measurement point, soil temperature and moisture (TDR 100 Soil Moisture Meter) in the first $7.5 \mathrm{~cm}$ were also detected.

\section{Nitrogen use efficiency}

$\mathrm{N}$ harvest index was calculated using the following equations:

$\mathrm{N}$ harvest index $(\mathrm{NHI})=\mathrm{N}$ uptake in marketable dry biomass $/ \mathrm{N}$ uptake in total dry biomass

$\mathrm{N}$ use efficiency (NUE) was evaluated using the approach suggested by Fageria et al. (2010) calculating: agronomic efficiency (AE), physiological efficiency (PE), agrophysiological efficiency (APE), apparent recovery efficiency (ARE), utilisation efficiency (EU). Nitrogen indexes were calculated using the following equations:

$\mathrm{AE}\left(\mathrm{mg} \mathrm{mg}^{-1}\right)=(\mathrm{Gf}-\mathrm{Gu}) / \mathrm{Na}$

$\mathrm{PE}\left(\mathrm{mg} \mathrm{mg}^{-1}\right)=(\mathrm{BYf}-\mathrm{BYu}) /(\mathrm{Nf}-\mathrm{Nu})$

$\operatorname{APE}\left(\mathrm{mg} \mathrm{mg}^{-1}\right)=(\mathrm{Gf}-\mathrm{Gu}) /(\mathrm{Nf}-\mathrm{Nu})$

$\operatorname{ARE}(\%)=[(\mathrm{Nf}-\mathrm{Nu}) / \mathrm{Na}] \times 100$

$\mathrm{EU}\left(\mathrm{mg} \mathrm{mg}^{-1}\right)=\mathrm{PE} \times \mathrm{ARE}$

where Gf is the marketable yield of the DSF fertilised plots (mg) (T50 or T100), Gu is the marketable yield of the mineral fertilised plots (mg) (Tmin), and $\mathrm{Na}$ is the quantity of nitrogen applied (mg), BYf is the biological yield (total biomass) of the DSF fertilised plots (mg) (T50 or T100), BYu is the biological yield of the mineral fertilised plots (mg) (Tmin), Nf is the nitrogen uptake (total biomass) of the DSF fertilised plots (T50 or T100), and $\mathrm{Nu}$ is the nitrogen uptake (total biomass) of the mineral fertilised plots (mg) (Tmin).

\section{Digestate solid fraction analysis}

The $\mathrm{pH}$ and electrical conductivity of DSF were determined according to EN13037 and EN13038, respectively. Dry matter was calculated following EN13040 and organic matter using EN13039. organic nitrogen was measured according to ISO1656; total organic carbon was calculated according to Nelson et al. (1996). Total contents of $\mathrm{P}, \mathrm{K}, \mathrm{Ca}, \mathrm{Mg}, \mathrm{Cd}, \mathrm{Cr}, \mathrm{Cu}, \mathrm{Ni}, \mathrm{Pb}, \mathrm{Zn}, \mathrm{Hg}$ and $\mathrm{Na}$ were determined using inductively coupled plasma atomic-emission spectrometry (ICP-AES) SPECTRO Ciros (Spectrum Italy Srl, Basiglio, Italy). In addition to fully characterise DSF, $\mathrm{NH}_{4}, \mathrm{NO}_{3}$, $\mathrm{PO}_{4}, \mathrm{Cl}$ and $\mathrm{SO}_{4}$ were determined using an ion chromatography system (ICS-900, Dionex Corp.) These analyses were conducted on DSF ash (Zancan et al., 2006) and in water extracts $(1: 6, \mathrm{v} / \mathrm{v})$ in order to check the soluble amount of macro and micro-nutrients.

\section{Carbon dioxide equivalent balance}

Considering only the DSF macronutrients $\left(\mathrm{N}, \mathrm{P}_{2} \mathrm{O}_{5}, \mathrm{~K}_{2} \mathrm{O}\right)$, and using the $\mathrm{CO}_{2}$ equivalent $\left(\mathrm{CO}_{2(\mathrm{eq})}\right)$ specific emission factors for mineral fertilisers production the environmental impact of fertilisation was analysed. The specific emission factors adopted to estimate the $\mathrm{CO}_{2(\mathrm{eq})}$ balance were $3.26 \mathrm{~kg} \mathrm{CO}$ (eq) emitted for each $\mathrm{kg}$ of $\mathrm{N}, 2.01 \mathrm{~kg} \mathrm{CO} \mathrm{CO}_{2 \text { (eq) }}$ emitted for each $\mathrm{kg}$ of $\mathrm{P}_{2} \mathrm{O}_{5}$ and $1.41 \mathrm{~kg}$ $\mathrm{CO}_{2(\mathrm{eq})}$ emitted for each $\mathrm{kg}$ of $\mathrm{K}_{2} \mathrm{O}$ (Capponi et al., 2012). The $\mathrm{CO}_{2(\mathrm{eq})}$ emissions due to the nutrients supplied by mineral fertilisers were counted as positive emission whereas the $\mathrm{CO}_{2(\mathrm{eq})}$ emissions due to the nutrients supplied by DSF were counted as avoided emissions with negative sign. The $\mathrm{CO}_{2(\mathrm{eq})}$ balance was calculated in terms of $\mathrm{CO}_{2(\mathrm{eq})} \mathrm{ha}^{-1}$.

\section{Statistical analysis}

Bio-agronomics data were analysed using ANOVA and the comparison between means was made using Fisher LSD test. NUE means were statistically processed by Fisher LSD test to compare crop species and by $t$ student test to compare fertilisation treatments. Soil $\mathrm{CO}_{2}$ emission data were not normal distributed therefore they were analysed with Kruskal-Wallis nonparametric test. Correlation between soil temperature and moisture with $\mathrm{CO}_{2}$ emissions were evaluated using Spearman Rank correlation.

Table 2. Macronutrients applied as mineral fertilisers or digestate solid fraction during horticulture succession.

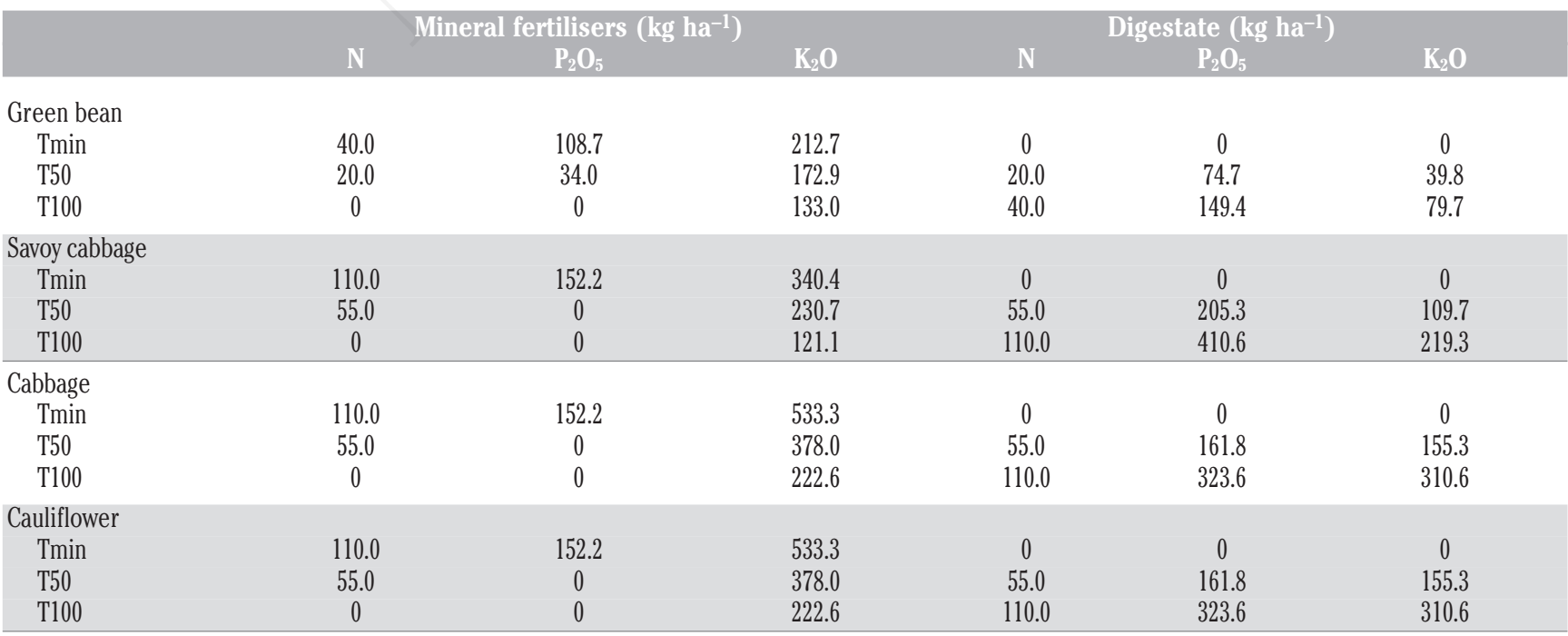

Tmin, 100\% of nitrogen crop requirement satisfied through mineral fertilisation; T50, 50\% of nitrogen crop requirement satisfied through mineral fertilisation and 50\% throught digestate solid fraction; T100, 100\% of nitrogen crop requirement satisfied through digestate solid fraction. 


\section{Results and discussion}

\section{Meteorological variables}

Meteorological data recorded during the experimental period are reported in Figure 1. Cumulative rainfall was $1016.4 \mathrm{~mm}$ (208.4 mm during green bean cultivation, $414.8 \mathrm{~mm}$ during savoy cabbage and $198.4 \mathrm{~mm}$ during cabbage and cauliflower cultivations), $16 \%$ higher than the average rain monitored in the same period in the previous 20 years. The average daily air temperature was $14.4^{\circ} \mathrm{C}$ with its maximum value at the end of the green bean crop season (June $12^{\text {th }} 2014,34.0^{\circ} \mathrm{C}$ ) and minimum value after savoy cabbage harvest (January $28^{\text {th }} 2015,-4.4^{\circ} \mathrm{C}$ ). The average solar radiation was $13.7 \mathrm{MJ} \mathrm{m}^{-2} \mathrm{~d}^{-1}$, with the higher monthly average intensity value registered in June 2014 (23.8 $\mathrm{MJ} \mathrm{m}^{-2} \mathrm{~d}^{-1}$ ); average daily wind speed was $2.0 \mathrm{~m} \mathrm{~s}^{-1}$.

A

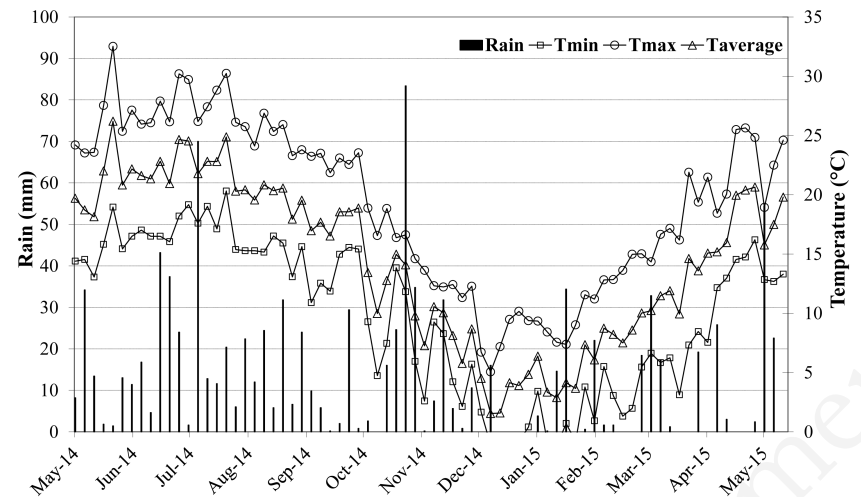

\section{Plants harvest and measurements}

The crops yield was not significantly influenced by the fertilisation treatments with an average ( \pm standard error) marketable yield of $9.0 \pm 0.5,9.9 \pm 1.2$ and $51.3 \pm 6.4 \mathrm{Mg} \mathrm{ha}^{-1}$ for green bean, cauliflower and cabbage, respectively. The savoy cabbage yield was significantly higher in the Tmin treatment than T100 one; T50 was not significantly different between the previous two treatments considering marketable yield whereas significant higher production was detected considering no marketable and total biomass than T100 treatment (Table 4).

Considering savoy cabbage yield, similar trend among fertilisation treatments was previously reported in the same areas by Nicoletto et al. (2012), although with higher absolute yield values. The different production is due to the lower $\mathrm{N}$ fertilisation in this study $(-26.7 \%)$ than that supplied by Nicoletto et al. (2012) that determine a marketable yield reduction of $26.1,38.8$ and $37.8 \%$ in the Tmin, T50 and T100 treatments, respectively. The higher per-

B

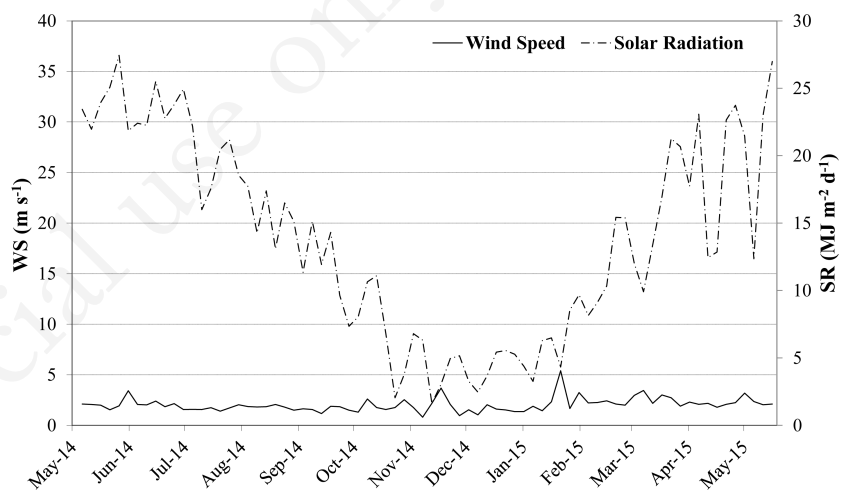

Figure 1. Meteorological data during experimental period. Five-day averages for temperatures and five-day cumulative rainfall (A), wind speed and solar radiation $(B)$.

Table 3. Soil chemical properties on dry matter basis.

\begin{tabular}{lcc} 
Parameters & \multicolumn{2}{c}{ Soil depth (m) } \\
& $0.00-0.30$ & $0.30-0.60$ \\
Nitrogen (\%) & 0.11 & 0.10 \\
Organic carbon (\%) & 0.87 & 0.78 \\
\hline $\mathrm{pH}$ & 7.57 & 7.77 \\
Electrical conductivity $\left(\mathrm{dS} \mathrm{m}^{-1}\right)$ & 0.27 & 0.25 \\
\hline Nitrites $\left(\mathrm{mg} \mathrm{kg}^{-1}\right)$ & 3.16 & 4.09 \\
Sodium $\left(\mathrm{mg} \mathrm{kg}^{-1}\right)$ & 22.4 & 18.0 \\
\hline Nitrates $\left(\mathrm{mg} \mathrm{kg}^{-1}\right)$ & 23.8 & 20.0 \\
Phosphates $\left(\mathrm{mg} \mathrm{kg}^{-1}\right)$ & 4.43 & 2.89 \\
\hline Sulphates $\left(\mathrm{mg} \mathrm{kg}^{-1}\right)$ & 59.9 & 23.9 \\
Magnesium $\left(\mathrm{mg} \mathrm{kg}^{-1}\right)$ & 32.2 & 29.6 \\
\hline Calcium $\left(\mathrm{mg} \mathrm{kg}^{-1}\right)$ & 256 & 239 \\
Chlorides $\left(\mathrm{mg} \mathrm{kg}^{-1}\right)$ & 13.4 & 4.46 \\
\hline Potassium $\left(\mathrm{mg} \mathrm{kg}^{-1}\right)$ & 14.3 & 12.0 \\
\hline
\end{tabular}

Table 4. Fresh biomass production $\left(\mathrm{Mg} \mathrm{ha}^{-1}\right)$.

\begin{tabular}{lrrr} 
Marketable & $\begin{array}{c}\text { No marketable } \\
\text { biomass }\end{array}$ & $\begin{array}{c}\text { Total } \\
\text { biomass }\end{array}$ \\
Green bean & & & \\
Tmin & $8.15 \pm 0.62$ & $11.50 \pm 0.33$ & $19.65 \pm 0.79$ \\
T50 & $9.36 \pm 0.86$ & $11.98 \pm 0.94$ & $21.34 \pm 1.74$ \\
T100 & $9.50 \pm 0.90$ & $11.84 \pm 1.04$ & $21.34 \pm 1.94$ \\
Sav0y cabbage & & & \\
Tmin & $25.87 \pm 1.03^{\mathrm{a}}$ & $25.58 \pm 1.79^{\mathrm{a}}$ & $51.44 \pm 2.76^{\mathrm{a}}$ \\
T50 & $20.81 \pm 2.33^{\mathrm{ab}}$ & $26.91 \pm 2.93^{\mathrm{a}}$ & $47.72 \pm 1.91^{\mathrm{a}}$ \\
T100 & $16.80 \pm 2.67^{\mathrm{b}}$ & $16.12 \pm 1.85^{\mathrm{b}}$ & $32.92 \pm 4.52^{\mathrm{b}}$ \\
\hline Cabbage & & & \\
Tmin & & & \\
T50 & $65.97 \pm 11.41$ & $33.61 \pm 9.82$ & $99.59 \pm 20.93$ \\
T100 & $41.14 \pm 7.15$ & $25.42 \pm 0.77$ & $66.56 \pm 7.91$ \\
Cauliflower & $46.79 \pm 11.59$ & $27.96 \pm 4.80$ & $74.74 \pm 16.33$ \\
Tmin & & & \\
T50 & $10.67 \pm 2.42$ & $23.38 \pm 2.45$ & $34.04 \pm 4.86$ \\
T100 & $8.94 \pm 2.95$ & $24.88 \pm 3.52$ & $33.82 \pm 4.13$ \\
\hline
\end{tabular}

Tmin, 100\% of nitrogen crop requirement satisfied through mineral fertilisation; $T 50,50 \%$ of nitrogen crop requirement satisfied through mineral fertilisation and 50\% throught digestate solid fraction; T100, $100 \%$ of nitrogen crop requirement satisfied through digestate solid fraction. a,b Different letters indicate significant differences for Fisher Least Significant Difference test at $\mathrm{P}<0.05$. 
centage reduction in our treatments with DSF respect Nicoletto et al. (2012) is maybe due to the different experimental period. In fact, in our study savoy cabbage was transplanted about four months after experiment beginning whereas in Nicoletto et al. (2012) after 2 years with higher nutrients (especially N) availability due to the residual effect of the previous crops cycles; moreover different cultivar were used. However, the one year succession results showed comparable fertilisation effect of digestate respect mineral fertilisation on summer and spring crops at both quantities supplied (T50 and T100) whereas lower DSF fertilisation effect was monitored for winter crop when $\mathrm{N}$ fertilisation was carried out using only digestate (T100). The lower production with DSF was probably due to the low environmental temperatures that reduced soil microbial activity, with a consequent reduction of the digestate nutrients availability in agreement with Alburquerque et al. (2012) and our previous results (Nicoletto et al., 2014). Considering that the yield of spring and summer crops is not influenced by the partial or total replace of inorganic fertilisers, this suggested that the use of digestate may reduce agricultural dependence on mineral fertilisers and the energy and economic costs associated with their use (Walsh et al., 2012).

As expected significant variations of $\mathrm{HI}$ and $\mathrm{NHI}$ were observed among crops. No significant differences were found between green bean and savoy cabbage with an average HI and NHI of 0.46 and 0.39 .

Crop species, on the average of DSF fertilisations (T50 and T100), significantly influenced the AE, ARE and UE indexes (Table 5), with negative indexes values for all species except for green bean, which showed positive values probably due to the higher symbiotic $\mathrm{N}_{2}$ fixation activity in the DSF treatments than $100 \%$ mineral one. Considering the AE, although cabbage and cauliflower were cultivated in the same period, they showed significant different values with lower AE cultivating cabbage. This difference can be traced at the different marketable part of the two species, vegetative part (leaves) in cabbage and reproductive part (inflorescence) in cauliflower. As well known, plants have higher $\mathrm{N}$ requirement to produce vegetative part than reproductive one. Considering the short DSF application time we can assume that DSF was not able to satisfy the cabbage $\mathrm{N}$ requirement. In fact, in the same year of the experiment reported in this paper, significant different AE values comparing cabbage and cauliflower cultivated in a long term DSF fertilisation trial (10 years) (unpublished data) were not observed. In view of this, to maximise the AE of $\mathrm{N}$ supplied with DSF, our results suggest that in the short-term (one year succession) cauliflower should be preferred at cabbage as spring crop.

Fertilisation treatment, on the average of crop species, exerted a significant effect only on ARE with negative values in both treatments with DSF (T50 and T100) and lower N recovery efficiency in the T100 than T50 (Table 6).

The negative ARE and UE indexes can be traced at the lower $\mathrm{N}$ availability in DSF treatments because in these last the $\mathrm{N}$ was supplied mainly in organic form and so need mineralisation process before crops uptake. Considering the slow turnover of organic matter in the soil, long-term studies are necessary to evaluate the nutrients use efficiency in agro-ecosystems managed for several years with DSF.

In economic terms the use of DSF has further advantages and some considerations have to be taken into account about the potential savings obtained by the farmer. Currently the cost of anaerobic digestate residues for fertilisation purpose can be quantified with only the transport and distribution of the raw material amounting to around $1.77 €$ for $\mathrm{N}$ units supplied with DSF. The same units of $\mathrm{N}$ provided with urea costs about $2.30 €$ (fertiliser purchase and distribution); consequently the application of $\mathrm{N}$ through digestate leads to an economic saving of about $23 \%$ in the fertilisation costs. Moreover, the addition of organic matter, together with the macronutrients required by the crop, involves considerable agronomic advantages in the long period by increasing the soil fertility. Additionally, the possibility of storing in the soil considerable amount of organic carbon, is aligned with what is required by recent European regulations relating to carbon management and the closure of the waste recovery cycle (Arthurson, 2009).

\section{Soil carbon dioxide flux measurement}

Soil $\mathrm{CO}_{2}$ emissions were not significantly influenced by fertilisation in all studied crops with median values always lower than $1 \mathrm{~g} \mathrm{~m}^{-2} \mathrm{~h}^{-1}$. Our results are in agree with Alburquerque et al. (2012) who reported no significant differences in terms of soil $\mathrm{CO}_{2}$

Table 5. Nitrogen use efficiency of four studied species on the average of digestate solid fraction fertilisation (T50 and T100).

\begin{tabular}{|c|c|c|c|c|c|}
\hline Species & $\mathrm{AE}\left(\mathrm{mg} \mathrm{mg}^{-1}\right)$ & PE (mg mg-1) & APE $\left(m g g^{-1}\right)$ & ARE (\%) & UE (mg mg-1) \\
\hline Green bean & $2.71^{\mathrm{a}}$ & $27.46^{\mathrm{a}}$ & $0.44^{\mathrm{a}}$ & $18.16^{\mathrm{a}}$ & $6.46^{\mathrm{a}}$ \\
\hline Savoy cabbage & $-4.75^{a b}$ & $24.85^{\mathrm{a}}$ & $1.33^{\mathrm{a}}$ & $-19.39^{b}$ & $-5.51^{a b}$ \\
\hline Cabbage & $-11.21^{b}$ & $18.12^{\mathrm{a}}$ & $14.39^{\mathrm{a}}$ & $-52.66^{\mathrm{b}}$ & $-14.68^{b}$ \\
\hline Cauliflower & $-0.93^{\mathrm{a}}$ & $19.94^{\mathrm{a}}$ & $-9.11^{\mathrm{a}}$ & $-17.27^{a b}$ & $-1.95^{\mathrm{ab}}$ \\
\hline
\end{tabular}

AE, agronomic efficiency; PE, physiological efficiency; APE, agrophysiological efficiency; ARE, apparent recovery efficiency; UE, utilisation efficiency. a,bDifferent letters indicate significant differences for Fisher Least Significant Difference test at $\mathrm{P}<0.05$.

Table 6. Nitrogen use efficiency of two digestate treatments on the average of crop species.

\begin{tabular}{lccccc} 
Theatment & AE $\left(m g g^{-1}\right)$ & PE $\left(m g g^{-1}\right)$ & APE $\left(m g g^{-1}\right)$ & ARE $(\%)$ & UE $(m g m g-1$ \\
T50 & $-3.79^{\mathrm{a}}$ & $29.74^{\mathrm{a}}$ & $3.72^{\mathrm{a}}$ & $-5.15^{\mathrm{a}}$ & $-2.06^{\mathrm{a}}$ \\
T100 & $-3.16^{\mathrm{a}}$ & $14.59^{\mathrm{a}}$ & $-0.33^{\mathrm{a}}$ & $-31.43^{\mathrm{b}}$ & $-5.80^{\mathrm{a}}$ \\
\hline
\end{tabular}

AE, agronomic efficiency; PE, physiological efficiency; APE, agrophysiological efficiency; T50, 50\% of nitrogen crop requirement satisfied through mineral fertilisation and 50\% throught digestate solid fraction; T100, $100 \%$ of nitrogen crop requirement satisfied through digestate solid fraction. ARE, apparent recovery efficiency; UE, utilisation efficiency. ${ }^{a}$ bDifferent letters indicate significant differences for t-student test at $\mathrm{P}<0.05$. 
emissions between mineral and digestate fertilisation in watermelon-cauliflower succession. The no significant different soil $\mathrm{CO}_{2}$ emission among fertilisation treatments (Tmin, T50, and T100) can be ascribed at the characteristics of organic matter content in the DSF. In fact, fresh organic matter addition can promote soil $\mathrm{CO}_{2}$ emission due to its easily decomposition by microbial activity (Fontaine et al., 2003), in opposite stabilised organic matter can maintain stable or decrease soil $\mathrm{CO}_{2}$ emission reducing microbial activity (Thomsen et al., 2013; Bachmann et al., 2014). The DSF used in this experiment came from a mesophilic $\left(35-40^{\circ} \mathrm{C}\right)$ anaerobic digestion plant that had a substrate retention time of $88-92$ days. Therefore, due to anaerobic digestion process characteristics, we can assume that with DSF was supplied stabilised organic matter that did not influence soil respiration in the experimental period (1 year). In fact, considering the $\mathrm{N}$ supplied $\left(260 \mathrm{~kg} \mathrm{ha}^{-1}\right)$ and the DSF composition (Table 1), during all succession the $\mathrm{C}$ added was 698 and $349 \mathrm{~g} \mathrm{~m}^{-2}$ in the T100 and T50 plots, respectively, whereas the $\mathrm{C}$ emitted from soil as total respiration was +59 and $-13 \mathrm{~g} \mathrm{~m}^{-2}$ in T100 and T50, respectively, compared with Tmin treatment.

The green bean, cultivated from May to July showed emission peaks that reach values of $4.5 \mathrm{~g} \mathrm{CO}_{2} \mathrm{~m}^{-2} \mathrm{~h}^{-1}$ and an emission median value of $0.46 \mathrm{~g} \mathrm{CO}_{2} \mathrm{~m}^{-2} \mathrm{~h}^{-1}$. During monitoring period soil $\mathrm{CO}_{2}$ emissions were positively correlated $(\mathrm{P}<0.01)$ with soil moisture that ranged between 12.9 and $35.5 \%$. No correlation was found between soil $\mathrm{CO}_{2}$ emissions and soil temperature that ranged between 17.2 and $34.7^{\circ} \mathrm{C}$.

The savoy cabbage, fall-winter crop, showed an emission median value among fertilisation treatments of $0.74 \mathrm{~g} \mathrm{CO}_{2} \mathrm{~m}^{-2} \mathrm{~h}^{-}$ ${ }^{1}$. In opposite of green bean, during savoy cabbage cropping season the soil $\mathrm{CO}_{2}$ emissions were positively correlated $(\mathrm{P}<0.01)$ with soil temperature that ranged between 4.3 and $31.6^{\circ} \mathrm{C}$, whereas no correlation was found with soil moisture ranged from 13.9 to $52.9 \%$. For cabbage and cauliflower, spring crops, were monitored soil $\mathrm{CO}_{2}$ emission median values of $0.84 \mathrm{~g} \mathrm{~m}^{-2} \mathrm{~h}^{-1}$ and $0.78 \mathrm{~g} \mathrm{~m}^{-2}$ $\mathrm{h}^{-1}$, respectively. During monitoring period soil $\mathrm{CO}_{2}$ emissions were positively correlated $(\mathrm{P}<0.01)$ with temperature (ranged from 15.3 to $31.2^{\circ} \mathrm{C}$ and from 11.7 to $31.5^{\circ} \mathrm{C}$ for cabbage and cauliflower, respectively) and negatively correlated $(\mathrm{P}<0.001)$ with soil moisture (ranged from 15.8 to $54.6 \%$ and from 15.8 to $47.7 \%$ for cabbage and cauliflower, respectively).

The seasonal variation in soil $\mathrm{CO}_{2}$ emission is commonly attributed to change in soil temperature, moisture or both (Davidson et al., 1998; Ding et al., 2007, 2010; Li et al., 2013). In our experiment summer and winter crops showed an opposite response considering these abiotic factors. When the minimum soil temperature is high $\left(17.2^{\circ} \mathrm{C}\right.$ in summer crop) the limiting factor is water availability for microorganism's activity whereas, during fall-winter crop season with lower temperature and wet condition soil temperature was the limiting factor. Considering spring crops, with intermediate condition than green bean and savoy cabbage, we assume that soil $\mathrm{CO}_{2}$ emission was positively correlate with soil temperature because of the positive effect on microbial activity after winter season whereas it was negatively correlate with soil moisture because high value of this last determine poor gas diffusion in the soil (Rochette et al., 1991).

$\mathrm{CO}_{2}$ green bean emission peaks, higher than other species, should be traced at the higher soil microbial activity due to the higher soil temperature with good soil moisture content whereas the increase in the soil $\mathrm{CO}_{2}$ emission median values following the crops cycles is probably explained by the organic matter accumulation.

The environmental impact, in terms of greenhouse gas emissions, is an important parameter to evaluate the possible substitution of mineral fertilisation with DSF in horticulture succession. Considering the $\mathrm{CO}_{2(\mathrm{eq})}$ balance between the quantity emitted in the atmosphere for chemical fertilisers production and the indirect $\mathrm{CO}_{2(\mathrm{eq})}$ saving due to fertilisation with DSF, in our experiment, as expected, positive emission balance was observed in the Tmin treatment. Always negative balance was calculated for T100 treatment whereas for T50 treatment it was positive for green bean crop and negative for other ones (Table 7).

\section{Conclusions}

Marketable yield of spring and summer species (green bean, cauliflower and cabbage) was not significantly influenced by fer-

Table 7. Carbon dioxide equivalent emissions to produce chemical fertilisers and saving carbon dioxide equivalent due to solid digestate use in this experiment.

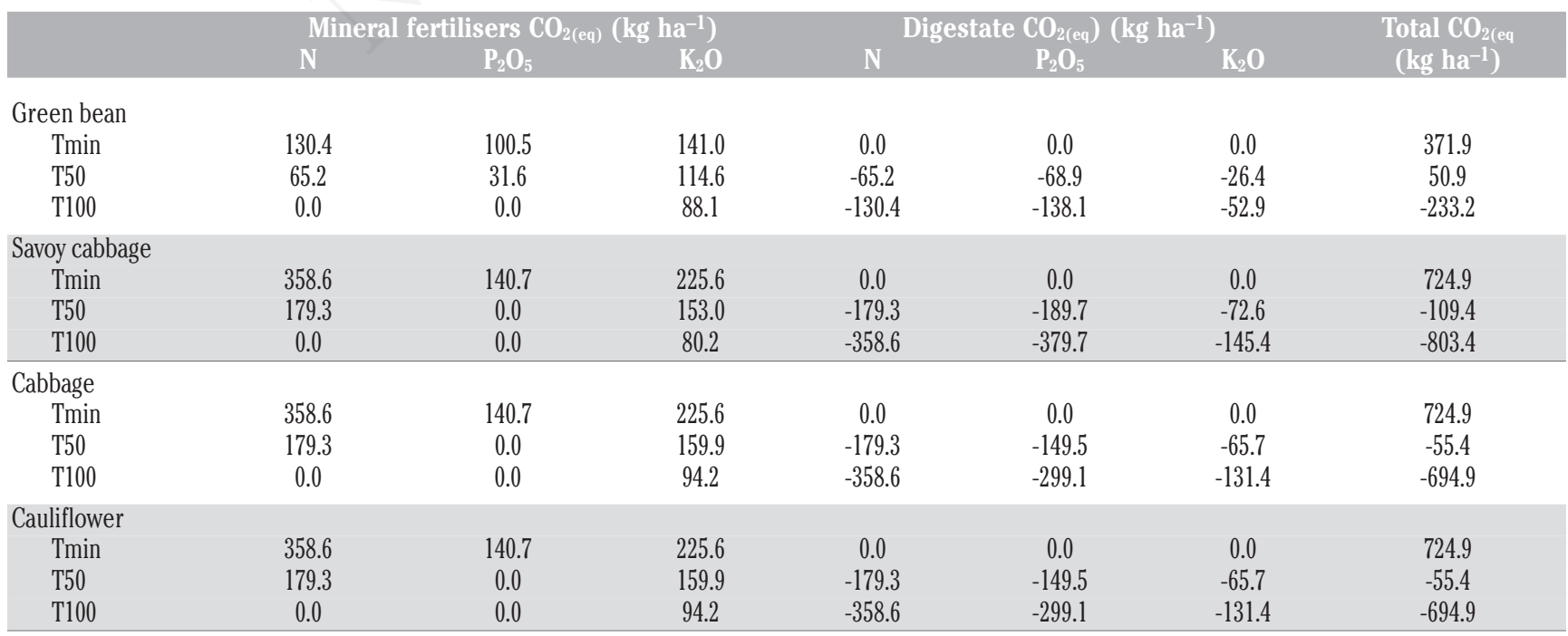

Tmin, 100\% of nitrogen crop requirement satisfied through mineral fertilisation; T50, 50\% of nitrogen crop requirement satisfied through mineral fertilisation and $50 \%$ throught digestate solid fraction; T100, $100 \%$ of nitrogen crop requirement satisfied through digestate solid fraction. Positive values indicate net $\mathrm{CO}_{2(\mathrm{eq})}$ emission whereas negative values indicate avoided $\mathrm{CO}_{2(\mathrm{eq})}$ emissions. 
tilisation treatment. Instead, the marketable yield of winter crop (savoy cabbage) was significantly higher with $\mathrm{N}$ mineral fertilisation than DSF one. On the contrary, when using both $\mathrm{N}$ mineral fertiliser and DSF at $50 \%$ the yield was not significantly different with respect to the previous two treatments. Therefore, our results suggest that DSF can be used to substitute $\mathrm{N}$ fertilisation in spring and summer species whereas during winter season it should be used to integrate $\mathrm{N}$ fertilisation. Partial or total fertilisation using DSF determined negative values of $\mathrm{N}$ apparent recovery efficiency and $\mathrm{N}$ use efficiency due to the slow turnover of organic matter in the soil suggesting that long term studies are desirable to evaluate the nutrients use efficiency in agro-ecosystems fertilised with organic matrices. The application of $\mathrm{N}$ through DSF leads to an economic saving of about $23 \%$ in the fertilisation costs respect urea. Soil $\mathrm{CO}_{2}$ emissions were not significantly influenced by fertilisation in all studied crops with median values always lower than $1 \mathrm{~g} \mathrm{~m}^{-2} \mathrm{~h}^{-1}$. Considering the $\mathrm{CO}_{2(\mathrm{eq})}$ quantity emitted in the atmosphere for chemical fertilisers production the partial or total fertilisation with DSF determined an indirect $\mathrm{CO}_{2(\text { eq) }}$ saving.

\section{References}

Alburquerque JA, De la Fuente C, Campoy M, Carrasco L, Nájera I, Baixauli C, Caravaca F, Roldán A, Cegarra J, Bernal MP, 2012. Agricultural use of digestate for horticultural crop production and improvement of soil properties. Eur. J. Agron. 43:119-28

Arthurson V, 2009. Closing the global energy and nutrient cycles through application of biogas residue to agricultural landpotential benefits and drawback. Energies 2:226-42.

Bachmann S, Gropp M, Eichler-Löbermann B, 2014. Phosphorus availability and soil microbial activity in a 3 year field experiment amended with digested dairy slurry. Biomass Bioenerg. 70:429-39.

Barbera AC, Maucieri C, Cavallaro V, Ioppolo A, Spagna G, 2013. Effects of spreading olive mill wastewater on soil properties and crops, a review. Agr. Water Manage. 119:43-53.

Bonetta S, Ferretti E, Bonetta S, Fezia G, Carraro E, 2011. Microbiological contamination of digested products from anaerobic co-digestion of bovine manure and agricultural byproducts. Lett. Appl. Microbiol. 53:552-7.

Capponi S, Fazio S, Barbanti L, 2012. $\mathrm{CO}_{2}$ savings affect the break-even distance of feedstock supply and digestate placement in biogas production. Renew. Energ. 37:45-52.

Casacchia T, Sofo A, Zelasco S, Perri E, Toscano P, 2012. In situ olive mill residual co-composting for soil organic fertility restoration and by-product sustainable reuse. Ital. J. Agron. 7:167-70

Cavalli D, Cabassi G, Borrelli L, Fuccella R, Degano L, Bechini L, Marino P, 2014. Nitrogen fertiliser value of digested dairy cow slurry, its liquid and solid fractions, and of dairy cow slurry. Ital. J. Agron. 9:71-8.

Chantigny $\mathrm{MH}$, Angers DA, Bélanger G, Rochette P, EriksenHamel N, Bittman S, Buckley K, Massé D, Gasser MO, 2008. Yield and nutrient export of grain corn fertilized with raw and treated liquid swine manure. Agron. J. 100:1303-9.

Davidson E, Belk E, Boone RD, 1998. Soil water content and temperature as independent or confounded factors controlling soil respiration in a temperate mixed hardwood forest. Glob. Change Biol. 4:217-27.

Ding W, Meng L, Yin Y, Cai Z, Zheng X, 2007. $\mathrm{CO}_{2}$ emission in an intensively cultivated loam as affected by long-term application of organic manure and nitrogen fertilizer. Soil Biol. Biochem. 39:669-79.

Ding W, Yu H, Cai Z, Han F, Xu Z, 2010. Responses of soil respiration to $\mathrm{N}$ fertilization in a loamy soil under maize cultivation. Geoderma 155:381-9.

Fageria NK, De Morais OP, Dos Santos AB, 2010. Nitrogen use efficiency in upland rice genotypes. J. Plant Nutr. 33:1696-711.

Fontaine S, Mariotti A, Abbadie L, 2003. The priming effect of organic matter: a question of microbial competition? Soil Biol. Biochem. 35:837-43.

Goberna M, Podmirseg SM, Waldhuber S, Knapp BA, García C, Insam H, 2011. Pathogenic bacteria and mineral $\mathrm{N}$ in soils following the land spreading of biogas digestates and fresh manure. Appl. Soil Ecol. 49:18-25.

Hossain N, Islam M, Alamgir M, Kibria MG, 2014. Growth Response of Indian Spinach to Biogas Plant Residues. IOSR J. Pharm. Biol. Sci. 9:1-6.

Li LJ, You MY, Shi HA, Ding XL, Qiao YF, Han XZ, 2013. Soil $\mathrm{CO}_{2}$ emissions from a cultivated Mollisol: Effects of organic amendments, soil temperature, and moisture. Eur. J. Soil Biol. 55:83-90.

Loria ER, Sawyer JE, Barker DW, Lundvall JP, Lorimor JC, 2007. Use of anaerobically digested swine manure as a nitrogen source in corn production. Agron. J. 99:1119-29.

Lošák T, Hlušek J, Válka T, Elbl J, Vítěz T, Bělíková H, Von Bennewitz E, 2016. The effect of fertilisation with digestate on kohlrabi yields and quality. Plant, Soil Environ. 62:274-8.

Marcato CE, Mohtar R, Revel JC, Pouech P, Hafidi M, Guiresse $\mathrm{M}, 2009$. Impact of anaerobic digestion on organic matter quality in pig slurry. Int. Biodeter. Biodegr. 63:260-266.

Marchetti R, Castelli F, Orsi A, Sghedoni L, Bochicchio D, 2012. Biochar from swine manure solids: influence on carbon sequestration and Olsen phosphorus and mineral nitrogen dynamics in soil with and without digestate incorporation. Ital. J. Agron. 7:189-95.

Maucieri C, Barbera AC, Borin M, 2016. Effect of injection depth of digestate liquid fraction on soil carbon dioxide emission and maize biomass production. Ital. J. Agron. 11:6-11.

Möller K, Müller T, 2012. Effects of anaerobic digestion on digestate nutrient availability and crop growth: a review. Eng. Life Sci. 12:242-57.

Montemurro F, Ferri D, Tittarelli F, Canali S, Vitti C, 2010. Anaerobic digestate and on-farm compost application: Effects on lettuce (Lactuca sativa L.) crop production and soil properties. Compost Sci. Util. 18:184-93.

Nelson DW, Sommers LE, Sparks DL, Page AL, Helmke PA, Loeppert RH, Soltanpour PN, Tabatabai MA, Johnston CT, Sumner ME, 1996. Total carbon, organic carbon, and organic matter. In: Methods of soil analysis, part 3-chemical methods. Soil Science Society of America, American Society of Agronomy, Madison, WI, USA, pp. 961-1010.

Nicoletto C, Santagata S, Sambo P, 2012. Effect of compost application on qualitative traits in cabbage. Acta Hortic. 1005:38995.

Nicoletto C, Santagata S, Zanin G, Sambo P, 2014. Effect of the anaerobic digestion residues use on lettuce yield and quality. Sci. Hort. 180:207-13.

Nkoa R, 2014. Agricultural benefits and environmental risks of soil fertilization with anaerobic digestates: a review. Agron. Sustain. Dev. 34:473-92.

Perelli M, Graziano PL, Calzavara R, 2009. Nutrire le piante. Arvan Ed., Venice, Italy. 
Rochette P, Desjardins RL, Pattey E, 1991. Spatial and temporal variability of soil respiration in agricultural fields. Can. J. Soil Sci. 71:189-96.

Tambone F, Genevini P, D'Imporzano G, Adani F, 2009. Assessing amendment properties of digestate by studying the organic matter composition and the degree of biological stability during the anaerobic digestion of the organic fraction of MSW. Bioresource Technol. 100:3140-2.

Tambone F, Scaglia B, D'Imporzano G, Schievano A, Orzi V, Salati S, Adani F, 2010. Assessing amendment and fertilizing properties of digestates from anaerobic digestion through a comparative study with digested sludge and compost. Chemosphere 81:577-83.

Teglia C, Tremier A, Martel JL, 2011. Characterization of solid digestates: part 1, review of existing indicators to assess solid digestates agricultural use. Waste Biomass Valoriz. 2:43-58.
Thomsen IK, Olesen JE, Møller HB, Sørensen P, Christensen BT, 2013. Carbon dynamics and retention in soil after anaerobic digestion of dairy cattle feed and faeces. Soil Biol. Biochem. 58:82-87.

Walsh JJ, Jones DL, Edwards-Jones G, Williams AP, 2012. Replacing inorganic fertilizer with anaerobic digestate may maintain agricultural productivity at less environmental cost. J. Plant Nutr. Soil Sc. 175:840-5.

Zancan S, Cesco S, Ghisi R, 2006. Effect of UV-B radiation on iron content and distribution in maize plants. Environ. Exper. Bot. 55:266-72.

Zhao Y, Wang P, Li J, Chen Y, Ying X, Liu S, 2009. The effects of two organic manures on soil properties and crop yields on a temperate calcareous soil under a wheat-maize cropping system. Eur. J. Agron. 31:36-42. 